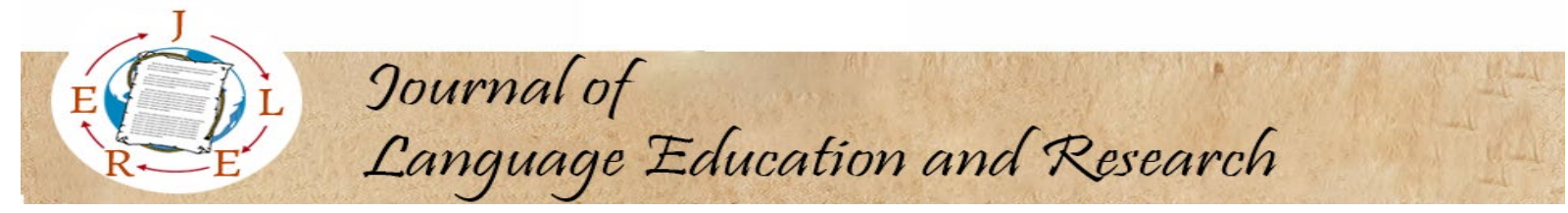

$7(2), 2021$

\author{
Journal of Language Education and Research
}

\author{
Research Article
}

\title{
Contextualized Teaching of Different Senses of "al-" in Turkish as a Foreign Language ${ }^{1 *}$
}

\author{
Deniz Ekin Yavaş ${ }^{2 * *}$ \\ Funda Uzdu Yıldız ${ }^{3 * * *}$
}

\begin{tabular}{l}
\hline ARTICLE INFO \\
\hline Received 03.04.2021 \\
Revised form 24.08.2021 \\
Accepted 20.10.2021 \\
Doi: $10.31464 /$ jlere.908777
\end{tabular}

Keywords:

Contextualized Teaching

Verbal Polysemy

Valence

Turkish as a Foreign Language

\begin{abstract}
Different types of word knowledge require different approaches to teaching. It is argued that learning different senses of words takes place through constantly encountering words in different contexts. Experimental studies also show that comprehension of unknown word senses (Iravani and Ghasemi, 2013) and ambiguity resolution of polysemous words (Watanabe, 2014) are facilitated when the context is available. Verbal polysemy is especially closely related to context. Verbs can show distributional differences in their different senses and verbs have different valences in some of their senses. Based on these relations between polysemy and context, this study aims to create sentence contexts for "al-", a high-frequency verb in Turkish, for contextualized teaching of its different senses in Turkish as a foreign language. The sentence contexts for different senses of the verb are created based on the information about its different senses' valences.
\end{abstract}

\begin{tabular}{ll}
\hline Acknowledgments & \\
Statement of Publication Ethics & Not Required \\
Authors' Contribution Rate & Both Authors Contributed Equally \\
Conflict of Interest & None. \\
\hline
\end{tabular}

\footnotetext{
$1 *$ This study is produced from the Master's thesis made in the Department of General Linguistics, Institute of Social Sciences, Dokuz Eylül University.

2* ORCID ID: https://orcid.org/0000-0003-2291-5618, deniz.eyavas@gmail.com

$3 * *$ Associate Professor, ORCID ID: https://orcid.org/0000-0003-1813-5432, Dokuz Eylül University, Department of General Linguistics, funda.uzdu@deu.edu.tr
} 


\section{Introduction}

Teaching meaning-form relationships is an important step of vocabulary teaching, but the number of known words alone is not enough to achieve proficiency in a foreign language; the depth of knowledge about known words is just as important. Therefore different types of knowledge about words must be learned, including their different senses.

Polysemy is a widely encountered phenomenon in natural languages and the majority of the words in a language have more than one sense. Because it is a widely encountered phenomenon and the number of senses is particularly high in high-frequency words, polysemy causes problems to foreign language learners at all levels. The studies (Schmitt, 1998, Karlsson, 2013; Öztürk, 2018) show that even advanced learner's knowledge of different senses is inadequate. This inadequacy leads to problems in foreign language teaching both in terms of language production and comprehension (Watanabe, 2014; Saito, Webb \& Trofimovich, 2016; Öztürk, 2017).

Different types of word knowledge require different approaches to teaching. Even though new words and their meaning-form relationship is taught more effectively with decontextualized activities, such as word lists, in order to deepen the knowledge of already known words and to teach different word knowledge types, such as collocations, constraints on usage, different senses, the contextualized approach should be adopted (Nagy, 1995; Horst, Cobb \& Meara, 1998; Waring \& Takaki, 2003; Webb, 2007; Schmitt, 2008; Nation \& Meara, 2010).

This study aims to create sentence contexts for "al-", the fourth most frequent verb in Turkish, for contextualized teaching of its different senses in Turkish as a foreign language. The sentence contexts for different senses of the verb are created based on its different senses' valences. This study is intended to be a model for contextualized teaching of different senses of verbs based on their differences in valence in general. Verbs show variety in their contextual distribution and their distributional richness is related to their semantic flexibility. Verbs change their meaning depending on the arguments that they are used with (Fellbaum, 1990, 1998; Lemmens, 1998). Therefore, polysemy is closely related to valence in verbs. Verbs differ in terms of their valences in some of their senses and the differences in valence can be seen in the number, semantic roles, grammatical functions and semantic properties of obligatory and optional arguments.

\section{Literature Review}

\section{Contextualized Teaching of Different Senses of Words}

Experimental studies (Prince, 1996; Laufer \& Schumeli, 1997; Webb, 2007; Mehrpour, 2008; Herusatoto, 2011; Ünald1, Bardakç1, Akpınar \& Dolaş, 2013; Sadeghi \& Nobakht, 2014) that compare the contextualized and decontextualized approach show that the decontextualized approach is more effective in terms of the number of words that can be taught in a certain period of time. However, a closer look at these studies reveals that these studies focus only on teaching new words and teaching the meaning-form relationship of words. 
The decontextualized approach is much more effective in terms of teaching a large number of words in a short period of time and also at the first stage when the meaning-form relationship of new words is learned. However, contextualized activities are more effective in the development of different word knowledge types and in the enrichment of the knowledge about words whose meaning-form relationship is already known (Nagy, 1995; Horst et al., 1998; Waring \& Takaki, 2003; Webb, 2007; Schmitt, 2008; Nation \& Meara, 2010). Webb (2007) states that studies that only measure the development of meaning-form relationships conclude that the contextualized activities do not have a significant effect on vocabulary teaching. But according to Webb (2007), different types of word knowledge should be examined if the effect of the context on vocabulary learning is to be determined.

Studies on the effect of contextualized activities on different word knowledge types (Pigada \& Schmitt, 2006, Webb, 2007, Baleghizadeh \& Nik, 2011) show that there is a positive relation between contextualized activities and different word knowledge types. Pigada \& Schmitt (2006) investigate the effect of intensive reading on the knowledge about spelling, grammatical features and meanings of words and conclude that the knowledge about the spelling of words is greatly improved as a result of intensive reading. Baleghizadeh \& Nik (2011) compare the effects of word lists and different context types (single sentence and paragraph) on teaching adjective+preposition and preposition+noun colligations and conclude that contextualized activities are more effective than word lists in teaching these colligations.

The knowledge of different senses is also another word knowledge type that is closely related to context and therefore is expected to benefit from the contextualized approach. Learning polysemous words starts with the core sense and as the duration of language learning increases, other senses of the words are learned. Studies (Schmitt, 1998; Crossley, Salsbury \& McNamara, 2010) show that learning different senses of polysemous words is a gradual process. In their study, Crossley et al. (2010) demonstrate that foreign language learners begin to learn and produce different senses of words after learning the core sense. Even though language learners use polysemous words in the early stages of learning, the use of other senses starts in the later stages.

Webb (2007) emphasizes the importance of context in learning different senses. Webb (2007) argues that the meaning of polysemous words is mostly only clear in context, therefore it is not very possible to learn such information with decontextualized activities, this information can only be learned from context. Learning different senses of words takes place over time through encountering different senses of words in different contexts (Schmitt, 2000, Bogaards, 2001). Bogaards (2001) states that words are used in different meanings in different contexts and that students encounter these contexts piece by piece. For this reason, learning words takes place over time through encountering different meanings in different contexts piece by piece. Similarly, Schmitt (2000) argues that the semantic limitations of words can be learned by constantly encountering words in different contexts. According to Schmitt (2000), each different context that the word is encountered increases the understanding of collocations, different meanings and other high-level knowledge of that word. In regard to teaching different senses of words, Hoshino, Sakata, Morimoto, Matsukubo \& Tsubaki (2018) emphasize the importance of well-structured materials. Hoshino et al. (2018) recommend that beginner-level texts should focus on core senses and after the core sense is learned, they should start focusing 
on different senses. For this purpose, it should be ensured that students encounter various expressions with different meanings of words in texts.

Experimental studies (Iravani \& Ghasemi 2013; Watanabe 2014) that focus on the relationship between context and polysemy support these views. Iravani \& Ghasemi (2013) examine the effects of 3 different types of clues (elaborated context, semantic frameworks and meaning chains) on the comprehension of unfamiliar meanings of polysemous words in EFL and conclude that the elaborated context is a more effective type of clue in regard to the comprehension of the meanings that are not familiar to students. Watanabe (2014) measures the effects of meaning relatedness and context constraint on lexical ambiguity resolution in EFL and shows that both meaning relatedness and context facilitate the process.

\section{Relation Between Verbal Polysemy and Valence}

Verbs are more flexible in meaning compared to the other part-of-speech categories and the reason for this is that they have more tendency to change their meaning depending on the arguments they are used with or co-occur with (Fellbaum, 1990, 1998; Lemmens, 1998). Verbs can show different distributional properties and have different valences in their different senses. Verbal polysemy is explained by polyvalence; having multiple valences (Leech, 1992; Rappaport Hovav \& Levin, 1998; Zaefferer, 2002; Levin \& Rappaport Hovav, 2005). The differences in valence can be seen in the number, semantic roles, grammatical functions and semantic properties of obligatory and optional arguments (Uzun, 1997; Vater, 2003; Uçar, 2009; Asher, 2011; Şen \& Turan, 2012; Spalek, 2015).

The differences in the number, semantic roles and semantic properties of obligatory and optional arguments are seen in the examples (1)-(2) from Vater (2003). The verb "gehen" ("to go') in German has two different meanings as in (1) and (2). In (1), the Goal argument "zum Bahnhof" ("to the station') is optional. On the contrary in (2), the Goal argument "nach London" ('to London') is obligatory and its omission leads to an ungrammatical sentence. In both (1) and (2), the Goal argument denotes a location. The comparison of the subjects of both these examples reveals that in these two constructions, semantic role and semantic properties of the subject differ. In (1), the subject has the semantic role Agent and it must be animate. On the contrary in (2), the subject has the semantic role Theme and must be inanimate.

(1) a. Paul geht zum Bahnhof.

'Paul is going to the station.'

b. Paul geht.

"Paul is going/walking."

(2) a. Der Brief geht nach London.

'The letter is going to London.'

b. *Der Brief geht.

(Vater, 2003: 104) 
Uzun (1997) gives examples from the verb "geç-" ('to pass') in Turkish and shows that in different senses this verb has a different number of arguments and grammatical functions of these arguments can also differ. In (3a-3g), different senses of "geç-" and example sentences are given.

a. Güneş ön camdan arka cama geçti. (“bir yerden başka bir yere geçmek”)

'The sun moved from the windscreen to the rear window.' ('to move from one place to another.')

b. Bu hastalık hayvanlardan insanlara geçer. ("bulaşmak")

'This disease is transmitted by animals to humans.' ('to be transmitted by (disease)')

c. Otobüs bu duraktan geçmez. ("uğramak")

'The bus does not pass by this stop.' (“to pass by")

d. Söyledikleri yazıya geçsin. ("yazmak, kaydetmek")

'Let what he/she said be written.' ("to write, to record")

e. Bu para artık geçmiyor. ("tedavülde olmak")

'This money is not valid anymore.' ('to be in circulation (money)')

f. Ali sınıfını geçti. ("bitirmek, başarmak”)

'Ali passed his class.' ('to finish, to achieve')

g. Bu haberi bütün gazetelere geçin. (“aktarmak, iletmek”)

'Pass this news to all newspapers.' ('to pass on, to convey')

(Uzun, 1997: 6)

In (3a) and (3b), the verb "geç-" has similar valence properties. In both these senses, the verb can take two objects; dative-marked (-(y)A) and ablative-marked (-DAn). In (3c), the verb only takes an ablative-marked object (-DAn) and in (3d), it takes a dative-marked object (-(y)A). In (3e), the verb is intransitive. In (3f), the verb only takes an accusative-marked object $(-(\mathrm{y}) \mathrm{I})$ and in (3g), it takes two objects; accusative-marked (-(y)I) and dative-marked (-(y)A).

Asher (2011) gives examples for the relation between the meaning of verbs and the semantic properties of their arguments. The verb "sweep" has two meanings depending on its direct object's semantic properties; whether it is a location or a portion of matter. Because the verb has different meanings with different types of objects, copredication and ellipsis with two different types of objects result in ungrammatical sentences in (4c) and (4d).

(4) a. John swept the kitchen and Mary the entryway.

b. John swept the dust and Mary the leaves.

c. \#John swept the kitchen and Mary the leaves.

d. \# John swept the kitchen and the dust.

(Asher, 2011: 33)

Another example that is given by Asher (2011) is the communication verbs. The meaning of the communication verbs, such as "shout", "whisper", "whistle", etc. changes according to whether or not they take an object and the type of objects they take as in (5).

a. John shouted (whispered, whistled, whined ... ). (activity) 

activity)

b. John shouted (whispered, whistled, whined . . . ) a warning. (accomplishment)

c. John shouted (whispered, whistled, whined ... ) at the animal. (accomplishment or

d. The bullets whistled past John. (accomplishment)

(Asher, 2011: 33)

Similarly, Spalek (2015) conducts a corpus-based study on the verbs "romper" (to break') and "cortar" ('to cut') in Spanish and concludes that different object types that these verbs can take result in different interpretations of these verbs.

There are several studies that focus on the relation between verbal polysemy and valence in Turkish (Uzun, 1997; Uçar, 2009; Şen \& Turan, 2012). These studies show that verbs have different valences in some of their senses in Turkish. Uzun (1997) classifies polysemy that is caused by the changes in valence as structural polysemy and determines four ways that these changes occur: obligatory arguments are added or removed, optional arguments are removed or optional arguments become obligatory arguments. In this study, Uzun (1997) focuses on only the semantic roles of the obligatory and optional arguments.

Uçar (2009) investigates the changes in valence of 90 verbs in Turkish that have five or more senses in dictionaries based on the classification of Uzun (1997). Uçar (2009) determines the changes in the number and semantic roles of the obligatory and optional arguments of these 90 verbs in their different senses. Şen and Turan (2012) analyze the number and the grammatical function of the obligatory arguments of 414 verbs in Turkish that are found in the dictionary under the letter "A". Uçar (2009) and Şen \& Turan (2012) focus on the different aspects of valence and they do not account for all aspects of valence; i.e. the number, semantic roles, grammatical function, semantic properties of obligatory and optional arguments. Also, both of these studies determine different senses of verbs based on Turkish dictionaries.

\section{Methodology}

\section{Selecting the Verb}

This study aims to create example sentence contexts for contextualized teaching of a high-frequency verb in Turkish; "al-" ('to take, to get'). This verb is selected for this study because of the strong relation between frequency and polysemy and the importance of teaching high-frequency words in foreign language vocabulary teaching ${ }^{4}$. The verb "al-" is the fourth most frequent verb in Turkish National Corpus (with 50,997,016 running words) (Aksan, Aksan, Mersinli \& Demirhan, 2017) with the raw frequency 312199 and a dispersion value of 0.97. First three verbs in the TNC corpus are the verbs "yap-" ('to do, to make'), "ol-" ("to be, to become') and "et-" ('to do, to make') which are mostly used as light verbs (Özbek, 2008;

\footnotetext{
4 See Yavaş (2020) for the application of this model to 8 other high-frequency verbs in Turkish; gel-, çık-, çalış-, geç-, kal-, aç-, dur-, bırak-.
} 
Uçar, 2009; Akşehirli, 2013). These verbs are eliminated because, as light verbs, they have limited contributions to the meaning and the valence of the complex predicate.

\section{Determining the Different Senses of "al-"}

Senses of "al-" that are included in this study are based on the findings of the Meaning Production Survey and Semantic Relatedness Survey conducted in Uçar (2009). In Uçar (2009), different meanings produced by the native speakers for a verb are accepted as different senses of that verb and the most frequently produced meaning is accepted as the core sense of that verb (Meaning Production Survey). Afterwards, different senses' semantic relatedness to the core sense is assessed through native speaker judgments and senses are classified as polysemy or homonymy based on their semantic relatedness (Semantic Relatedness Survey). The senses classified as homonymy in Uçar (2009) are not included in this study.

Based on these findings, the verb "al-" has four different senses;

1) Beğendiği arabayı sonunda aldı.

'He/She finally bought the car he/she liked.'

2) Postacidan mektubu aldi.

'He/She received the letter from the postman.'

3) Masanın üstündeki kalemi aldı.

$\mathrm{He} / \mathrm{She}$ took the pen, which was on the table.'

4) Milli atlet altın madalyayı aldı.

'The national athlete received the gold medal.'

(Uçar, 2009: 519)

In sense 1, "al-" has the meaning 'to buy something'; in sense 2, it has the meaning "to receive or get something'; in sense 3, it has the meaning 'to take, pick up or grab something' and in sense 4 , it has the meaning 'to receive or win a reward, prize, medal, etc.'.

\section{Valence Analysis}

For valence analysis of "al-", valences of different senses of "al-" are analyzed. First, the number, grammatical functions and semantic roles of the obligatory arguments are determined. Afterwards, the semantic roles that the verb can take as optional arguments are determined. Finally, different senses are compared in order to determine the differences in the semantic properties of the arguments. This comparison is made between the senses that show similarity in their valence.

Semantic roles that can be an optional argument in every sense, such as Cause, Time, Manner, and Comitative are not included in the analysis. Some verbs accept the roles of Force and Instrument in the subject position, however, Force and Instrument roles in the subject position are not included in the analysis. 


\section{Creating Example Sentence Contexts}

At this stage, example sentence contexts are created based on the valences determined for each verb sense in the previous stage. Three example sentence contexts are created for each situation of valence possibilities: obligatory arguments, obligatory arguments + one optional argument, obligatory arguments+another optional argument, and so on.

In this study, the proficiency level is not taken into account, and therefore, it is aimed that the example contexts are suitable for all levels. For this reason, simple structures and simple and frequent words are used in the creation of the example contexts. Furthermore, in some examples, additional sentences are included in order to reinforce the meaning of the verb.

It is also intended to support and reinforce the verb meaning with the chosen words and structures. Words, phrases and structures that are frequently used with the verb are used and these are determined through searches in the TSCorpus ${ }^{5}$ (Sezer and Sezer, 2013; Sezer, 2016, 2017) and online search engines.

\section{Results}

\section{Valence Analysis of "al-"}

The verb "al-" has four different senses;

1) to buy something

2) to receive or get something

3) to take, pick up or grab something

4) to receive or win a reward, prize, medal, etc.

In sense 1, the verb "al-" requires two obligatory arguments; Agent role as subject and Theme role as direct object ${ }^{6}$ as in (6). As for optional arguments; "al-" can take the roles of Source role as an ablative-marked NP (mağaza-dan 'from the store', firın-dan 'from the bakery', etc.) as in (7), Beneficiary role as an indirect object (Ayşe'ye 'for Ayşe', kardeşim-e 'for my little sister/brother', sevgilim-e 'for my boyfriend/girlfriend', etc.) as in (8), Instrument role as a comitative/instrumental-marked NP (kredi kart1-yla 'with a credit card', nakit parayla 'with cash', hediye çeki-yle 'with gift card', etc.) as in (9) and Price role as a dative-marked NP (5 lira-ya 'for 5 lira', etc.) as in (10).
(6) Esin
kalem
ald1.
Esin-NOM
pencil-ACC
Agent
Theme
'Esin bought a pencil.'
(7) Esin
firın-dan
ekmek aldı.
Esin-NOM
bakery-ABL bread-ACC

\footnotetext{
5 http://tscorpus.com

${ }^{6}$ Direct object of a sentence is marked with the accusative case in Turkish, although accusative case marker sometimes is not realized depending on the definiteness of the NP.
} 
Agent Source Theme

'Esin bought bread from the bakery."

(8) Esin

Ayşe'ye çiçek

ald1.

Esin-NOM Ayşe-DAT flower-ACC

Agent Beneficiary Theme

'Esin bought flowers for her mother"

(9) Esin

kredi kart1-yla

kitap

ald1.

Esin-NOM credit card-INST book-ACC

Agent

Instrument

Theme

'Esin bought a book with a credit card.'

$\begin{array}{lll}\text { Esin } & 5 \text { lira-ya } & \text { kitap } \\ \text { Esin-NOM } & 5 \text { lira-DAT } & \text { book-ACC } \\ \text { Agent } & \text { Price } & \text { Theme }\end{array}$

ald1.

'Esin bought a book for 5 lira.'

In sense 2, the verb "al-" requires two obligatory arguments; Receiver role as subject and Theme role as direct object as in (11). As for optional arguments; "al-" can only take the role of Giver role as an ablative-marked NP (okul-dan 'from the school', postac1-dan 'from the postman', Ali'den 'from Ali', etc.) as in (12).

$\begin{array}{lll}\text { Esin } & \text { mektup aldi. } \\ \text { Esin-NOM } & \text { letter-ACC }\end{array}$

Receiver

Theme

'Esin received a letter.'

$\begin{array}{lll}\text { Esin } & \text { okul-dan } & \text { belge-yi ald1. } \\ \text { Esin-NOM } & \text { school-ABL } & \text { document-ACC } \\ \text { Receiver } & \text { Giver } & \text { Theme }\end{array}$

'Esin received the documents from the school.'

In sense 3, the verb "al-" requires two obligatory arguments; Agent role as subject and Theme role as direct object as in (13). As for optional arguments; the verb "al-" can take the roles of Source role as an ablative-marked NP (çanta-dan 'from the bag', masa-dan 'from the table', çekmece-den 'from the drawer', etc.) as in (14) and Instrument role as a comitative/instrumental-marked NP (maşa-yla 'with tongs', kaşık-la 'with the spoon', elim-le 'with my hand', etc.) as in (15).

$\begin{array}{ll}\text { Esin } & \text { kalem-i aldi. } \\ \text { Esin-NOM } & \text { pencil-ACC } \\ \text { Agent } & \text { Theme } \\ \text { 'Esin took the pencil.' }\end{array}$

$$
\text { Esin çanta-dan cüzdan-1 aldı. }
$$




$\begin{array}{lll}\text { Esin-NOM } & \text { bag-ABL } & \text { wallet-ACC } \\ \text { Agent } & \text { Source } & \text { Theme }\end{array}$

'Esin took her wallet from her bag.'

$\begin{array}{llll}\text { Esin } & \text { et-i } & \text { maşa-yla aldı } \\ \text { Esin-NOM } & \text { meat-ACC } & \text { tongs-INST } & \\ \text { Agent } & \text { Theme } & \text { Instrument } & \end{array}$

'Esin picked up the meat with tongs.'

In sense 4, the verb "al-" requires two obligatory arguments; Receiver role as subject and Theme role as direct object as in (16). As for optional arguments; "al-" can take the roles of Giver role as an ablative-marked NP (devlet-ten 'from the government', UNESCO'dan 'from UNESCO', etc.) as in (17), Location role as a locative-marked NP (olimpiyatlar-da 'in the Olympics", Cannes Film Festivalinde 'at the Cannes Film Festival', Almanya'da 'in Germany', vb.) as in (18) and Attribute role as a locative-marked NP (yüzme-de 'in swimming', edebiyat kategorisi-nde 'in the literature category', etc.) as in (19).

$\begin{array}{ll}\text { Esin } & \text { madalya aldi. } \\ \text { Esin-NOM } & \text { medal-ACC } \\ \text { Receiver } & \text { Theme }\end{array}$

\begin{tabular}{|c|c|c|}
\hline Proje & UNESCO'dan & ödül \\
\hline project-NOM & UNESCO-ABL & award-ACC \\
\hline Receiver & Giver & Theme \\
\hline \multicolumn{3}{|c|}{ 'The project received an award from UNESCO' } \\
\hline Proje & Almanya'-da & ödül \\
\hline project-NOM & Germany-LOC & award-ACC \\
\hline Receiver & Location & Theme \\
\hline \multicolumn{3}{|c|}{ 'The project received an award in Germany.' } \\
\hline Esin & yüzme-de & madalya \\
\hline Esin-NOM & swimming-LOC & medal-ACC \\
\hline Receiver & Attribute & Theme \\
\hline
\end{tabular}

Table 1. Different Senses of "al-" and Their Valences

\begin{tabular}{lcc}
\hline Meaning & Obligatory Arguments & Optional Arguments \\
\hline 1. to buy something & Agent, Theme & Source, Instrument, Beneficiary, Price \\
\hline $\begin{array}{l}\text { 2. to receive or get } \\
\text { something }\end{array}$ & Receiver, Theme & Giver \\
\hline
\end{tabular}




\begin{tabular}{llc}
\hline $\begin{array}{l}\text { 3. to take, pick up } \\
\text { or grab something }\end{array}$ & Agent, Theme & Source, Instrument \\
\hline $\begin{array}{l}\text { 4. to receive or win } \\
\begin{array}{l}\text { a reward, prize, } \\
\text { medal, etc. }\end{array}\end{array}$ & Receiver, Theme & Giver, Location, Attribute \\
\hline
\end{tabular}

Table 1 contains information about valences of different senses of "al-". In terms of their obligatory arguments' number, semantic roles and grammatical functions, sense 1 and sense 3 (Agent-subject/Theme-direct object) and sense 2 and sense 4 (Receiver-subject/Themedirect object) are similar. However, even though sense 1 and sense 3 show similarity in their obligatory arguments, these two senses take different optional arguments. This is also the case with sense 2 and sense 4 .

Sense 1 can take the roles Source, Beneficiary, Instrument and Price as optional arguments. On the other hand, sense 3 can only take the roles Source and Instrument as optional arguments. Even though these senses can both take the Source and Instrument roles, semantic properties of these two arguments differ in both senses. In sense 1, the Source argument must be a place where the act of buying can happen ${ }^{7}$ as in (20a), on the other hand, this argument can be any physical place in sense 3 as in (20b). In sense 1, the Instrument argument must be an instrument for buying, such as money, and credit card as in (21a), and in sense 3, it must be an instrument for holding or grasping objects, such as gloves, and tongs as in (21b).

$\begin{array}{clll}\text { a. Esin } & \text { firın-dan } & \text { ekmek aldı. } \\ \text { Esin-NOM } & \text { bakery-ABL } & \text { bread-ACC } & \\ \text { Agent } & \text { Source } & \text { Theme } & \end{array}$

(sense 1)

'Esin bought bread from the bakery.'

b. Esin çanta-dan cüzdanı ald1. (sense 3)

Esin-NOM bag-ABL wallet-ACC

Agent Source Theme

'Esin took her wallet from her bag.'

$\begin{array}{ll}\text { a. Esin } & \text { kredi kartı-yla } \quad \text { kitap ald1. } \\ \text { Esin-NOM } & \text { credit card-INST book-ACC } \\ \text { Agent } & \text { Instrument Theme }\end{array}$

'Esin bought a book with a credit card.'

b. Esin et-i maşayla aldı.

Esin-NOM meat-ACC tongs-INST

Agent Theme Instrument

'Esin picked up the meat with tongs.'

As for sense 2 and sense 4, both of these senses can take the Giver semantic role as an optional argument but in sense 2, this argument must be a person from which the receiving of an object can happen as in (22a). In sense 4, this argument must be an organization, such as an

\footnotetext{
7 This argument even does not have to be a physical location, as in the example "internetten" "from the internet'.
} 
institution, a corporation that can give rewards, prizes, etc. as in (22b) The Receiver and the Theme argument also has different semantic properties in these two senses. In sense 4, the Receiver argument can be inanimate as well, as opposed to sense 2 as in (22a) and (22b). In sense 2, this argument must be human. In sense 4 , the Theme argument must be an object that can be won, such as a prize and a reward as in (23b). But in sense 2, the Theme argument can be any object that can be received as in (23a).

$\begin{array}{lll}\text { a. Esin } & \text { Ali'den } & \text { belgeyi aldi. } \\ \text { Esin-NOM } & \text { Ali-ABL } & \text { document-ACC } \\ \text { Receiver } & \text { Giver } & \text { Theme }\end{array}$

'Esin received the documents from Ali.'
b. Proje UNESCO'dan ödül ald1. (sense 4) project-NOM UNESCO-ABL award-ACC
Receiver Giver Theme
'The project received an award from UNESCO'
a. Esin
mektup
ald1.
(sense 2)

Esin-NOM letter-ACC

Receiver Theme

'Esin received a letter.'

b. Esin madalya ald1.

(sense 4)

$\begin{array}{ll}\text { Esin-NOM } & \text { medal-ACC } \\ \text { Receiver } & \text { Theme }\end{array}$

'Esin received a medal.'

\section{Example Sentence Contexts for Different Senses of "al-"}

In this section, the example sentence contexts for each sense of "al-" are listed. They are created based on the properties of their valence determined in the previous section. The phrases that are used in the example contexts, and the obligatory and optional arguments that these phrases correspond to can be found in the tables (2-5).

\section{Example Sentence Contexts for Sense 1}

Table 2. Phrases Used in the Creation of Sentence Contexts for Sense 1

\begin{tabular}{ll}
\hline Semantic Roles & Phrases \\
\hline Agent* & $\begin{array}{l}\text { ben, sen, o, arkadaşım, o (Beste), o (Cem), İrem, siz } \\
(\mathrm{I}, \text { you (sing.), he/she, my friend, she (Beste), he (Cem), Irem, you } \\
(\text { pl. }))\end{array}$
\end{tabular}


Theme*

Source

Beneficiary

Instrument

Price hangi çantay1/ hangisini, hiçbir şey, yeni bir elbise, ekmek, eski kitaplar, bu kitabı, bu kazağı, oyuncak, çiçek, bu eşyaları, su, kahveyi, kazağını, kalem, defter, arabanızı

(which bag/which one, nothing, a new dress, bread, old books, this book, this sweater, toy, flowers, these things, water, coffee, her sweater, pencil, notebook, your car(pl.))

bakkaldan, sahaftan, internetten

(from the grocery store, from the second-hand bookstore, from the internet)

bana, ona (kardeşime), sevgilisine

(me, him/her (brother/sister), for his/her boyfriend/girlfriend)

hediye çekiyle, bozuk paralarımla, kredi kartıyla

(with the gift card, with my coins, with credit card)

10 liraya, 2 liraya, 6 liraya, ne kadara/kaça

(for 10 lira, for 2 lira, for 6 lira, for how much money)

*: obligatory arguments

Sentence contexts created with Agent and Theme arguments:

1) İki çantayı da çok beğendim. Sence hangi çantayı/hangisini almalıyım?

'I really liked both bags. Which bag/which one do you think I should buy?'

2) Hiçbir şey alamadım çünkü mağazadaki her şey çok pahalıydı.

'I couldn't buy anything because everything in the store was too expensive.'

3) Yeni bir elbise aldım.

'I bought a new dress.'

Sentence contexts created with Agent, Theme and Source arguments:

4) Bakkaldan ekmek alır misın?

'Can you buy bread from the grocery store?'

5) Sahaftan eski kitaplar ald1.

'He/She bought old books from the second-hand bookstore.'

6) Bu kitabı internetten aldım, internette daha ucuzdu.

'I bought this book online, it was cheaper on the internet.'

Sentence contexts created with Agent, Theme and Beneficiary arguments:

7) Arkadaşım bana bu kazağı aldı ama kazağın rengini beğenmedim/üstüme olmadı/küçük geldi.

'My friend bought me this sweater, but I didn't like its colour/it doesn't fit me/it is small for me.'

8) Gelecek Perşembe kardeşimin doğum günü. Ona oyuncak alacağım. 
'Next Thursday is my brother's/sister's birthday. I'll buy him/her a toy.'

9) Yılbaşında sevgilisine çiçek almış.

'He/She bought flowers for his/her boyfriend/girlfriend for New Year's Eve."

Sentence contexts created with Agent, Theme and Instrument arguments:

10) Beste geçen ay bir çekilişte hediye çeki kazanmıştı. O yüzden bu eşyaları hediye çekiyle aldi.

'Beste won a gift card in a draw last month. That's why she bought these things with the gift card.

11) Bozuk paralarımla su aldım.

'I bought water with my coins.'

12) Cem'in nakit parası yoktu, o yüzden kahveyi kredi kartıyla aldı.

'Cem didn't have cash, so he bought the coffee with credit card.'

Sentence contexts created with Agent, Theme and Price arguments:

13) Irem kazağını 10 liraya aldı.

'Irem bought her sweater for 10 lira.'

14) 2 liraya kalem, 6 liraya da defter ald1.

'He/She bought a pencil for 2 lira and a notebook for 6 lira."

15) Arabanızı ne kadara/kaça aldınız?

'For how much did you buy your car?'

\section{Example Sentence Contexts for Sense 2}

Table 3. Phrases Used in the Creation of Sentence Contexts for Sense 2

\begin{tabular}{ll}
\hline Semantic Roles & Phrases \\
\hline Receiver* & $\begin{array}{l}\text { Beste, sen, ben, başkan } \\
\text { (Beste, you, I, the president) }\end{array}$ \\
Theme* & mektubu, öğretmenin e-mailini, bir mektup, belgeleri, \\
& paray1, fişi \\
& (the letter, the teacher's email, a letter, the documents, \\
& the money, the receipt) \\
& sekreterden, ondan (Cem'den), kasiyerden \\
& (from the secretary, from him (from Cem), from the \\
& cashier)
\end{tabular}

*: obligatory arguments 
Sentence contexts created with Receiver and Theme arguments:

1) Cem bir ay önce Beste'ye mektup yollamıştı. Beste mektubu bugün almış.

'Cem sent a letter to Beste a month ago. Beste has received the letter today.'

2) Öğretmenin e-mailini aldın $\mathrm{mi}$ ?

'Have you received the teacher's email?'

3) Dün bir mektup aldım ama kim gönderdi bilmiyorum.

'I received a letter yesterday but I don't know who sent it.'

Sentence contexts created with Receiver, Theme and Giver arguments:

4) Başkan sekreterden belgeleri aldi.

'The president received the documents from the secretary.'

5) Parayı Cem'e vermiştim, ondan parayı aldın mı?

'I gave the money to Cem, did you get the money from him?'

6) Kasiyerden fişi almadım.

'I didn't get the receipt from the cashier.'

\section{Example Sentence Contexts for Sense 3}

Table 4. Phrases Used in the Creation of Sentence Contexts for Sense 3

\begin{tabular}{|c|c|}
\hline Semantic Roles & Phrases \\
\hline Agent* & $\begin{array}{l}\text { o, ben, İrem Cem'in babası, annesi } \\
\text { (he/she, I, Irem, Cem's father, his/her mother) }\end{array}$ \\
\hline Theme* & $\begin{array}{l}\text { gitarını, kağıt, kalem, telefonumu, çantasını, bir kitap, } \\
\text { cüzdanımı, tencereyi, topu, camları } \\
\text { (his/her guitar, a paper, a pen, my phone, his/her bag, a } \\
\text { book, my wallet, the pot, the ball, the glass) }\end{array}$ \\
\hline Source & $\begin{array}{l}\text { odadan, kitaplıktan, çantamdan } \\
\text { (from the room, from the bookcase, from my bag) }\end{array}$ \\
\hline Instrument & $\begin{array}{l}\text { eldivenle, sopayla, süpürgeyle } \\
\text { (with gloves, with a stick, with a broom) }\end{array}$ \\
\hline
\end{tabular}

*: obligatory arguments

Sentence contexts created with Agent and Theme arguments:

1) Gitarını aldı ve şarkı çalmaya başladı.

'He/She took his/her guitar and started playing a song.' 
2) Kağıt, kalem aldım ve adresi kağıda yazdım.

'I took a paper and a pen and wrote the address on the paper.'

3) Arkadaşımı arayacaktım. Telefonumu aldım ama şarjı yoktu ve kapanmıştı.

'I was going to call my friend. I picked up my phone but its battery had died and it was turned off.'

Sentence contexts created with Agent, Theme and Source arguments:

4) İrem odadan çantasını aldı.

'Irem took her bag from the room.'

5) Kitapliktan bir kitap ald1.

'He/She took a book from the bookcase.'

6) Çantamdan cüzdanımı aldım.

'I took my wallet from my purse.'

Sentence contexts created with Agent, Theme and Instrument arguments:

7) Tencere çok sicaktı, o yüzden tencereyi eldivenle ald1.

'The pot was very hot, so he/she took the pot with gloves.'

8) Çocuklar top oynuyorlardı ve top ağaca takıldı. Cem'in babası topu sopayla aldı.

'The children were playing ball and the ball got caught in the tree. Cem's father took the ball with a stick.'

9) Bardak kırıldı ve her yer cam oldu. Annesi camları süpürgeyle aldı.

'The glass was broken and it was everywhere. His/her mother swept the glass.'

\section{Example Sentence Contexts for Sense 4}

Table 5. Phrases Used in the Creation of Sentence Contexts for Sense 4 başkanımız, okulumuzun projesi, milli sporcular, film, okulumuzun öğrencileri, Michael Phelps, Türkiye (Irem, our team, this story, my grandfather, the businessman, our head of department, our school project, national athletes, the film, students in our school, Michael Phelps, Turkey) 
(a certificate of achievement, a trophy, an award, many medals, a plaquet, a gold medal, many awards, a medal)

Giver

vakıftan, devletten, üniversiteden

(from the foundation, from the government, from the university)

Location

Almanya'da, olimpiyatta, festivallerde, yarışmada

(in Germany, in the Olympics, at festivals, in the competition)

Attribute

genç kategorisinde, güreşte, yüzmede

(in the junior category, in wrestling, in swimming)

*: obligatory arguments

Sentence contexts created with Receiver and Theme arguments:

1) İrem çok çalışkan bir öğrenci. O yüzden yıl sonunda başarı belgesi aldı. 'Irem is a very hard-working student. That's why she received a certificate of achievement at the end of the year.'

2) Takımımız turnuvada birinci oldu ve kupa aldı.

'Our team won the tournament and won a cup.'

3) Bu öykü, öykü yarışmasında en iyi öykü seçildi ve ödül aldı.

'This story was selected as the best short story in the short story competition and received an award.'

Sentence contexts created with Receiver, Theme and Giver arguments:

4) Dedem savaş zamanında askerdi ve bu yüzden devletten birçok madalya aldı.

'My grandfather was a soldier in wartime and therefore he received many medals from the government.'

5) İş adamı yıl boyunca vakfa birçok bağışta bulundu ve yıl sonunda vakıftan plaket aldı.

'The businessman made many donations to the foundation throughout the year and he received a plaquet from the foundation at the end of the year.'

6) Bölüm başkanımız üniversiteden ödül aldı.

'Our head of department received an award from the university.'

Sentence contexts created with Receiver, Theme and Location arguments:

7) Okulumuzun projesi Almanya'da ödül ald1.

'Our school's project was awarded in Germany.'

8) Milli sporcular olimpiyatta altın madalya aldı.

'National athletes won a gold medal in the Olympics.'

9) Sinemaya yeni bir film geldi. Film festivallerde birçok ödül almış. 
'A new movie came to the cinema. The movie has received many awards at festivals.'

Sentence contexts created with Receiver, Theme and Attribute arguments:

10) Okulumuzun öğrencileri, yarışmada genç kategorisinde madalya ald1.

'Students in our school won a medal in the junior category in the competition.'

11) Türkiye güreşte birçok madalya aldı.

'Turkey won many medals in wrestling.'

12) Michael Phelps yüzmede toplam 11 altın madalya aldı.

'Michael Phelps won a total of 11 gold medals in swimming.'

\section{Discussion}

The valence analysis of the verb "al-" shows that "al-" has different valences in its different senses. The differences in its valence are seen in the number, grammatical functions, semantic roles and semantic properties of the obligatory and optional arguments. These findings are in line with other studies that study the relationship between verbal polysemy and valence in Turkish (Uzun, 1997; Uçar, 2009; Şen \& Turan, 2012).

All of the examined senses of "al-" differ in terms of their obligatory and optional arguments and if these arguments are shared among senses, they appear to have different semantic properties. As a result, it was possible to create example sentence contexts that are different from each other for each verb sense, both in terms of grammatical functions and semantic properties of the phrases that are used.

\section{Conclusion}

This study aims to determine the relation between valence and polysemy of the verb "al-" in Turkish and to use this information in contextualized teaching of different senses of "al-" in Turkish as a foreign language. First, valences of different senses of "al-" are analyzed. Afterwards, example sentence contexts are created for each verb sense based on their valence for the purpose of contextualized teaching of the different senses of "al-" in Turkish as a foreign language.

In this study, the senses of the verb are limited to the findings of the Meaning Production Survey and Semantic Relatedness Survey applied to native speakers in Uçar (2009). However, of course, conscious meaning production of native speakers does not fully reflect the diversity of the meanings of verbs. But this study is carried out for educational purposes and it is assumed that the meaning production of native speakers reveals the most frequent senses of that verb. The frequency of senses is as much as important as the frequency of the words in foreign language teaching. High-frequency senses are learned earlier than less frequent senses (Schmitt, 2010: 54). Therefore, the teaching should also start with the more frequent senses and continue with the less frequent ones. Unfortunately, there is no study in Turkish that investigates the sense frequencies of highly polysemous verbs, such as "al-". 
This study is intended to be a model for contextualized teaching of different senses of verbs. In future studies, the model developed in this study can be applied to different verbs in Turkish and to different languages as well. This study does not take into account the proficiency level. In future studies, the level of proficiency can be taken into account in adapting the model. Verbs and their senses can be selected according to the level of proficiency and the grammatical structures and words that are suitable for that level can be used in the creation of the sentence contexts.

\section{References}

Adolphs, S. \& Schmitt, N. (2003). Lexical Coverage of Spoken Discourse. Applied linguistics. 24(4): 425-438.

Adolphs, S. \& Schmitt, N. (2004). Vocabulary Coverage According to Spoken. Vocabulary in a Second Language: Selection, Acquisition, and Testing (pp. 39-51). Editors P. Bogaards \& B. Laufer. Amsterdam: John Benjamins Publishing.

Aksan, Y., Aksan, M., Mersinli, Ü., \& Demirhan, U. U. (2017). A Frequency Dictionary of Turkish. Taylor \& Francis.

Akşehirli, S. (2013). Türkçede Et- Katkısız Eyleminin Sözlüksel İşlevleri. Turkish Studies. 8(9): 481-494.

Asher, N. (2011). Lexical Meaning in Context: A Web of Words. Cambridge: Cambridge University Press.

Baleghizadeh, S., \& Nik, A. B. (2011). The Effect of Type of Context on EFL Learners' Recognition and Production of Colligations. Journal of Language and Linguistic Studies. 7(1): 100-112.

Bogaards, P. (2001). Lexical Units and the Learning of Foreign Language Vocabulary. Studies in Second Language Acquisition. 23(3): 321-343.

Brugman, C. (2001). Light Verbs and Polysemy. Language Sciences. 23(4-5): 551-578.

Carter, R. (2012). Vocabulary. New York: Routledge.

Crossley, S., Salsbury, T. \& McNamara, D. (2010). The Development of Polysemy and Frequency Use in English Second Language Speakers. Language Learning. 60(3): 573-605.

Fellbaum, C. (1990). English Verbs as a Semantic Net. International Journal of Lexicography. 3(4), 278-301.

Fellbaum, C. (1998). A Semantic Network of English: The Mother of All WordNets. EuroWordNet: A Multilingual Database with Lexical Semantic Networks (pp. 137148). Editor P. Vossen.

Göksel, A., \& Kerslake, C. (2005). Turkish: A Comprehensive Grammar. Routledge. Herusatoto, H. (2012). Longer EFL Vocabulary Retention: Learning in Context or in Isolation?. LINGUA: Jurnal Ilmu Bahasa dan Sastra. 6(2): 181-183. 
Horst, M., Cobb, T. \& Meara, P. (1998). Beyond a Clockwork Orange: Acquiring Second Language Vocabulary Through Reading. Reading in a Foreign Language. 11: 207-23. Dordrecht, Springer.

Hoshino, Y., Sakata, N., Morimoto, S., Matsukubo, A. \& Tsubaki, M. (2018). The Meaning Distributions of a Polysemous Word in Two Kinds of EFL Learning Materials. Journal of Bunkyo Gakuin University. 17: 35-56.

Hu, H. M. \& Nation, P. (2000). What Vocabulary Size is Needed to Read Unsimplified Texts. Reading in a Foreign Language. 8: 689-696.

Iravani, H., \& Ghasemi, M. D. (2013). A Comparison of Using Three Different Types of Cues, Elaborated Context, Semantic Frames and Meaning Chains, in Disambiguating Polysemous Verbs. International Journal of English Language Education. 1(1), 109129.

Karlsson, M. (2013). Quantitative and Qualitative Aspects of Advanced Learners' L1 and L2 Mastery of Polysemous Words. Hermes-Journal of Language and Communication Studies. 51: 79-112.

Laufer, B. (1992). How Much Lexis is Necessary for Reading Comprehension?. Vocabulary and Applied Linguistics (pp. 126-132). Editors P. J. Arnaud \& H. Bejoint. London: Palgrave Macmillan.

Laufer, B. (1997). The Lexical Plight in Second Language Reading: Words You Don't Know, Words You Think You Know, and Words You Can't Guess. Second Language Vocabulary Acquisition: A Rationale for Pedagogy (pp. 20-34). Editors J. Coady \& T. Huckin. Cambridge: Cambridge University Press.

Laufer, B. \& Shmueli, K. (1997). Memorizing New Words: Does Teaching Have Anything to Do with it?. RELC JOURNAL. 28(1): 89-106.

Leech, G. (1992). Corpora and theories of linguistic performance. Directions in corpus linguistics, 105-122.

Lemmens, M. (1998). Lexical perspectives on transitivity and ergativity. Benjamins.

Levin, B. \& Rappaport Hovav, M. (2005). Argument Realization. Cambridge: Cambridge University.

Mehrpour, S. (2008). A Comparison of the Effects of Two Vocabulary Teaching Techniques. The Asian EFL Journal. 10(2): 192-208.

Miyamoto, T. (2000). The Light Verb Constructions in Japanese: The Role of the Verbal Noun. Philadelphia: John Benjamins Publishing Company.

Morimoto, S., \& Loewen, S. (2007). A Comparison of the Effects of Image-Schema Based Instruction and Translation-Based Instruction on the Acquisition of L2 Polysemous Words. Language Teaching Research. 11(3): 347-372.

Nagy, W. E. (1995). On the Role of Context in First-and Second-Language Vocabulary Learning. Champaign.: University of Illinois at Urbana-Champaign.

Nation, I. S. P. (1993). Vocabulary Size, Growth, and Use. The Bilingual Lexicon (pp. 115134). Editors R. Schreuder \& B. Weltens. Amsterdam: John Benjamins Publishing. 
Nation, I. S. P. (2006). How Large a Vocabulary is Needed for Reading and Listening?. Canadian Modern Language Review. 63(1): 59-82.

Nation, I. S. P. (2011). Research into Practice: Vocabulary. Language Teaching. 44(4): 529539.

Nation, P., \& Waring, R. (1997). Vocabulary Size, Text Coverage and Word Lists. Vocabulary: Description, Acquisition and Pedagogy. 14: 6-19.

Nation, P. \& Meara, P. (2010). Vocabulary. An Introduction to Applied Linguistics (pp. 3453). Editor N. Schmitt. London: Hodder Education.

Özbek, A. (2008). Support Verb Constructions in Turkish. Annals of Japan Association for Middle East Studies. 24(1), 1-16.

Özbek, A. (2010). On Çek- as a Light Verb-A Contrastive View from Japanese. Dil ve Dilbilimi Çalışmaları Dergisi 6(1): 1-13.

Öztürk, M. (2017) Words with Multiple Meanings in Authentic L2 Texts: An analysis of Harry Potter and the Philosopher's Stone. The Reading Matrix: An International Online Journal. 17(2): 133-141.

Öztürk, M. (2018). Acquisition of Noun Polysemy in English as a Foreign Language. Journal of Foreign Language Education and Technology. 3(1): 83-109.

Pigada, M. \& Schmitt, N. (2006). Vocabulary Acquisition from Extensive Reading: A Case Study. Reading in a Foreign Language. 18(1): 1-28.

Prince, P. (1996). Second Language Vocabulary Learning: The Role of Context versus Translation as a Function of Proficiency. The Modern Language Journal. 80: 478- 493

Qian, D. D. (2002). Investigating the Relationship Between Vocabulary Knowledge and Academic Reading Performance: An Assessment Perspective. Language Learning. 52(3): 513-536.

Rappaport Hovav, M. \& Levin, B. (1998). Building Verb Meanings. The Projection of Arguments: Lexical and Compositional Factors (pp. 97-134.). Editors M. Butt \& W. Geuder. Stanford: CSLI Publications.

Sadeghi, K. \& Nobakht, A. (2014). The Effect of Linguistic Context on EFL Vocabulary Learning. GEMA Online Journal of Language Studies. 14(3).

Saito, K., Webb, S., \& Trofimovich, P. (2016) Lexical Profiles of Comprehensible Second Language Speech: The Role of Appropriateness, Fluency, Variation, Sophistication, Abstractness, and Sense Relations. Studies in Second Language Acquisition. 38: 677701.

Schmitt, N. (1998). Tracking the Incremental Acquisition of Second Language Vocabulary: A Longitudinal Study. Language Learning. 48(2): 281-317.

Schmitt, N. (2000). Vocabulary in Language Teaching. Cambridge: Cambridge University Press.

Schmitt, N. (2008). Instructed Second Language Vocabulary Learning. Language Teaching Research. 12(3): 329-363. 
Schmitt, N. (2010) Researching Vocabulary: A Vocabulary Research Manual. London: Palgrave Macmillan.

Schmitt, N., Jiang, X., \& Grabe, W. (2011). The Percentage of Words Known in a Text and Reading Comprehension. The Modern Language Journal. 95(1): 26-43.

Sezer, T. (2017). TS Corpus Project: An Online Turkish Dictionary and TS DIY Corpus. European Journal of Language and Literature. 9(1), 18-24.

Sezer, T. (2016). Tweets Corpus: Building a Corpus by Social Media. Journal of National Education and Social Sciences. 210: 621-633

Sezer, T. \& Sezer, B. (2013). TS Corpus: Herkes İçin Türkçe Derlem. Proceedings 27th National Linguistics Conference, 217-225.

Spalek, A. A. (2015). Spanish Change of State Verbs in Composition with Atypical Theme Arguments: Clarifying the Meaning Shifts. Lingua. 157: 36-53.

Stevenson, S., Fazly, A., \& North, R. (2004). Statistical Measures of the Semi-Productivity of Light Verb Constructions. Proceedings of the Workshop on Multiword Expressions: Integrating Processing. 1-8.

Şen, E. \& Turan, S. (2012). Türkçede Eylemlerin Altulam Özellikleri ve Bu Özelliklerin Eğitim-Öğretim Ortamlarına Aktarılması. Dil Dergisi. 158: 7-36.

Uçar, A. (2007). Eylemde Çokanlamlılık ve Sözlük Girdisi Olarak Katkısız Eylemler XXI. Ulusal Dilbilim Kurultayı Bildirileri 10 (pp.137-145) Editors Y. Aksan \& M. Aksan. Mersin: Mersin University.

Uçar, A. (2009). Türkçede Eylemlerde Çokanlamlılık: Uygunluk Kuramı Çerçevesinde Bir Çözümleme [Unpublished doctoral dissertation]. Ankara University Graduate School of Social Sciences.

Uçar, A. (2010). Light Verbs Constructions in Turkish Dictionaries: Are They Submeanings of Polysemous Verbs?. Journal of Linguistics and Literature.7(1): 1-17.

Uzun, N. E. (1997). Türkçe Eylemlerde Çokanlamlılık ve Rol Kuramı. A. Ü. Tömer Dil Dergisi. 51 (1), 5-20.

Ünaldı, I., Bardakçı, M., Akpınar, K. D. \& Dolaş, F. (2013). A Comparison of Contextualized, Decontextualized and Corpus-Informed Vocabulary Instruction: A Quasi-Experimental Study. Dil ve Edebiyat Eğitimi Dergisi. 2(8): 78-95.

Vater, Heinz (2003). Valency and Diathesis. Motivation in Languages: Studies in Honor of Günter Radden (pp. 99-122) Editors H. Cuyckens, T. Berg, R. Dirven and K. Panther. Amsterdam: John Benjamins.

Waring, R. \& Takaki, M. (2003). At What Rate Do Learners Learn and Retain New Vocabulary from Reading a Graded Reader? Reading in a Foreign Language. 15: 130163

Watanabe, Y. (2014). Effects of Contextual Constraint on the Processing of Polysemous Words in Japanese EFL Reading. KATE Journal. 28: 55-68.

Webb, S. (2007). Learning Word Pairs and Glossed Sentences: The Effects of a Single Context on Vocabulary Knowledge. Language Teaching Research. 11(1): 63-81. 
Yavaş, D. E. (2020). Contextualized Teaching of Polysemous Verbs in Turkish as a Foreign Language [Unpublished master's thesis]. Dokuz Eylul University Graduate School of Social Sciences.

Zaefferer, D. (2002). Polysemy, polyvalence, and linking mismatches: the concept of RAIN and its codings in English, German, Italian, and Spanish. DELTA: Documentação de Estudos em Lingüística Teórica e Aplicada, 18(SPE), 27-56. 